\title{
Mekansal değişimin alüviyal fanlar üzerinde oluşan toprakların özelliklerine etkisi
}

\section{The effect of spatial change on the properties of soil formed on alluvial fans}

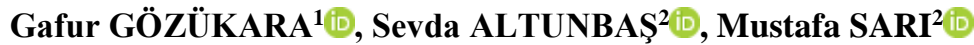

${ }^{1}$ Eskișehir Osmangazi Üniversitesi, Ziraat Fakültesi, Toprak Bilimi ve Bitki Besleme Bölümü, Eskişehir

${ }^{2}$ Akdeniz Üniversitesi, Ziraat Fakültesi, Toprak Bilimi ve Bitki Besleme Bölümü, Antalya

Sorumlu yazar (Corresponding author): G. Gözükara, e-posta (e-mail): ggozukara@ogu.edu.tr

Yazar(lar)e-posta (Author e-mail): saltunbas@akdeniz.edu.tr, musari.toprak@gmail.com

\section{MAKALE BİLGİSİ}

Alınış tarihi 08 Nisan 2019

Düzeltilme tarihi 10 Eylül 2019

Kabul tarihi 10 Eylül 2019

\section{Anahtar Kelimeler:}

Burdur Gölü

Alüviyal ana materyal

Toprak oluşumu ve gelişimi

\section{ÖZ}

Günümüzde dramatik bir şekilde çekilmeye devam eden Burdur Gölü'nün dinamik su seviyesinde Pliyosen ve Kuvaterner dönemlerde önemli düşüşler meydana gelmiştir. Pliyosen ve Kuvaternerin başlarında, iklimsel parametrelerdeki değişiklikler ve tektonik çökmeler sonucunda, sudan karasal ortama geçen arazileri, farklı büyüklükteki akarsular aşındırarak, taşıdıkları materyalleri Burdur gölünün eski göl tabanlarına depolamışlardır. Bu çalışmanın amacı, alüviyal fanların üzerinde gelişen toprakların pedogenetik ve jeogenetik gelişimi ve özelliklerini tespit etmektir. Araştırma kapsamında alüviyal ana materyal üzerinde gelişen, Kuvaterner yaşlı 12 pedon tanımlanmıștır. Söz konusu pedonlar A-C horizon dizilimine sahiptir. Kuvaterner dönemi boyunca, başta klimatoloji olmak üzere tüm toprak oluşum faktörleri, profillerde B horizonunun oluşmasına yeterli olamamıştır. Ancak toprak oluşum faktörleri ve göl topoğrafyasında meydana gelen değişimler, toprakların morfolojik, fiziksel ve kimyasal özelliklerinde önemli farklılara neden olmuştur. Bu farkll1kklar toprak profillerinde; $\mathrm{pH}$ değerinin 7.59-8.94, tuzluluk içeriklerinin 0.21-2.93 $\mathrm{dS} \mathrm{m}^{-1}$, kireç içeriklerinin $\% 15.98-46.48$, organik madde miktarlarının \%0.17-9.40, kil içeriğinin \%4.74-70.66, suda çözünebilir anyonlardan; $\mathrm{CO}_{3}^{-2} 0.08-0.68 \mathrm{meq} \mathrm{l}^{-1}, \mathrm{HCO}_{3}^{-} 0.56-3.04 \mathrm{meq} \mathrm{l} \mathrm{l}^{-1}, \mathrm{Cl}^{-} 1.00-7.80$ meq $\mathrm{l}^{-1}, \mathrm{SO}_{4}^{-2}$ 0.12-30.97 meq 1 ${ }^{-1}$, değişebilir Na 0.09-3.34 meq $100 \mathrm{~g}^{-1}$, değişebilir $\mathrm{K} 0.10-2.25$ meq $100 \mathrm{~g}^{-1}$, değişebilir $\mathrm{Ca}+\mathrm{Mg}$ 9.45-26.39 meq $100 \mathrm{~g}^{-1}$, KDK değerleri 11.10-28.39 meq $100 \mathrm{~g}^{-1}$, ESP değerinin 0.39-14.05 arasinda değişmesine neden olmuştur. Toprak özelliklerindeki bu mekansal farklılıklar ile Burdur Gölü'nün güncel sınırına yaklaştıkça, pedogenetik olarak ayrışma-değişim-dönüşüm gibi işlemlerin göreceli olarak azaldığı tespit edilmiştir.

\section{ARTICLE INFO}

Received 08 April 2019

Received in revised form 10 September 2019 Accepted 10 September 2019

\section{Keywords:}

Lake Burdur

Alluvial parent material

Soil formation and development

\begin{abstract}
At the dynamic water level of the Burdur Lake, which continues to be drawn dramatically today, significant decreases have occurred in the pliocene and quaternary periods. At the beginning of Pliocene and Quaternary, as a result of the changes in climatic parameters and tectonic collapses, the terraces which were transferred from the water to the terrestrial environment were eroded by the streams of different sizes and stored the materials they carried in the old lake bases of Lake Burdur. The aim of this study is to determine pedogenetic and geogenetic development and properties of soils on alluvial fans. In the scope of the study, 12 quaternary pedons developed on the alluvial fans were identified. These pedons have the A-C horizon sequence. During the Quaternary period, all soil formation factors, especially climatology, were not sufficient to form the B horizon in the profiles. However, soil formation factors and changes in lake topography have caused significant differences in morphological, physical and chemical properties of soils. These differences in soil profiles caused ranging from; $\mathrm{pH}$ 7.59-8.94, electrical conductivity $0.21-2.93 \mathrm{dS} \mathrm{m}^{-1}$, lime \%15.98-46.48, organic matter \%0.17-9.40, clay \%4.74-70.66, $\mathrm{CO}_{3}^{-2} 0.08-0.68 \mathrm{meq} \mathrm{1}^{-1}, \mathrm{HCO}_{3}^{-} 0.56-3.04 \mathrm{meq}{ }^{-1}, \mathrm{Cl}^{-}$ 1.00-7.80 meq ${ }^{-1}, \mathrm{SO}_{4}^{-2} 0.12-30.97$ meq $^{-1}$, changeable Na 0.09-3.34 meq $100 \mathrm{~g} \mathrm{~g}^{-1}$, changeable $\mathrm{K}$ 0.10-2.25 meq $100 \mathrm{~g}^{-1}$, changeable $\mathrm{Ca}+\mathrm{Mg}$ 9.45-26.39 meq $100 \mathrm{~g}^{-1}$, CEC $11.10-28.39$ meq $100 \mathrm{~g}^{-1}$, ESP $0.39-14.05$. As these spatial differences in soil characteristics approached the current boundary of Burdur Lake, it was determined that the processes like pedogenetically decomposition-change-transformation decreased relatively.
\end{abstract}




\section{Giriş}

Bugün göller yöresi olarak isimlendirilen bölgenin, geçmişte ve günümüzde irili ufaklı pek çok göle sahip olduğu bilinmektedir. Bölgede bu kadar çok göl olması, jeolojik dönemlerde farklı sürelerde göl ve sığ deniz suları ile kaplı olması nedeniyledir. Bölgenin en önemli göllerinden birisi olan ve çalışma konumuzu oluşturan Burdur gölü, bir Ramsar alanıdır. Ramsar kriterleri kapsamında altı metreyi geçmeyen kısımları "sulak alan" olarak tescil edilmiş olan Burdur Gölü'nün bazı yerleri, geçmiş jeolojik zaman süreçlerinde çeşitli kereler ve çeşitli düzeylerde çekilmek suretiyle karasal ortama kavuşmuştur (Atalay 1977; Roberts ve ark. 2003; Ataol 2010; Tudryn ve ark. 2013). Bu gölün özellikle günümüzdeki çekilmesi ise çok hızlı ve dramatik bir biçimde devam etmektedir (Gözükara ve ark. 2017, 2018, 2019; Gözükara 2019). Göller, genellikle bulundukları yörenin en çukur topografyalarında yer alırlar. $\mathrm{Bu}$ ortamlar, bulundukları topografyaları gereğince çevrelerindeki yüksek arazilerden dönemsel yüzey akışlarıyla taşınan taşl1-topraklı materyaller ile doldurulurlar. Farklı jeolojik devir ve dönemlerde, iklimsel parametreler ve tektonizma sonucunda göl seviyesinin azalması ile ortaya çıkan göl materyalleri (lakustrin) üzerine, çeşitli büyüklükteki mevsimlik/sürekli yüzey suları ve akarsular tarafından taşınarak getirilen malzemeleri depolarlar (Gözükara 2019). Karasal ortama çıkan lakustrin ana materyallerin üzerini örten bu alüviyal materyallerde, mekansal farklılıklara bağlı olarak pedolojik değişim ve dönüşüm yaşanır. Söz konusu değişim ise toprak özelliklerinde önemli farklılıklar meydana getirmektedir. Hatta bu farklılıklar coğrafi birlik içerisinde aynı ana materyal ve iklim koşullarında gelişen fakat fizyoğrafya, eğim, erozyon ve drenaj faktörlerinin etkisi ile katena düzeyinde farklılaşan toprak özellikleri ile arazi ve toprakların sürdürülebilir yönetimine ve üretkenlik potansiyellerine ilişkin kararların verilmesinde büyük öneme sahip olmaktadır (Dinç ve Şenol 1990; Dinç ve ark. 1991; Altunbaş ve Sarı 1998; Sarı ve ark. 2003; Altunbaş 2005; Altunbaş ve Sarı 2010; Altunbaş ve Sar1 2011; Gözükara 2019). Toprak oluşumu ve gelişimi için zaman ve mekan faktörleri toprakların özelliklerini ve onların ayrışma oranlarını belirler. Bu etki zamanla morfolojik, fiziksel, kimyasal ve mineralojik özelliklerin değişimi ve gelişimi ile değişik sayılarda horizonların oluşmasını ve farklılaşmasını sağlar (Sarı ve ark. 2003; Mutlu 2010; Altunbaş ve Sarı 2011; Gözükara 2019). Bu farklılaşma başlangıç olarak elementlerin toprak profili içinde yeniden dağılımı, horizonlaşma ve son olarak da bu dağılıma bağlı olarak toprak tiplerinin farklılaşması olarak ortaya çıar. Ancak toprak oluşumu için geçen zaman aynı olsa bile diğer toprak yapan faktörlerin farklı oranlardaki etkisi ile toprakların morfolojisi ve fiziko-kimyasal özellikleri farklılık gösterebilir (Sarı 2015; Gözükara 2019).

Farklı konumsal dağılıma sahip alüviyal ana materyal üzerinde çeşitli düzeylerde pedolojik değişim ve dönüşümlerin yaşanmış ve halen de yaşanıyor olması kaçınılmazdır. Burdur Göl Havzası'nda çeşitli nedenlerle bir kısmı tarımsal üretimde kullanılmakta olan toprakların oluşum ve gelişimlerinin hangi düzeylerde olduğu ve aynı zamanda bu toprakların mekansal farklılıkların neler olduğuna dair sistematik ve bütüncül bir araştırma bulunmamaktadır. $\mathrm{Bu}$ araştırma, Burdur Gölü Havzası'nın belirli bölümünün farklı mekanlarındaki alüviyal ana materyal üzerinde gelişen toprakların morfolojik, fiziksel ve kimyasal özelliklerinin tespit edilmesi ve bu toprakların pedolojik oluşum ve gelişim düzeylerindeki mekansal farklılıklarının belirlenmesi amacıyla planlanmıştır. Elde edilen bu verilerin havzadaki arazilerin planlanmasında kullanılarak günümüzde dramatik bir şekilde yok oluşa doğru giden Burdur Gölü'nün ve çevresinin korunması ile ekolojik devamlılığına katk1 sağlaması hedeflenmektedir.

\section{Materyal ve Metot}

\subsection{Materyal}

Araştırma, Türkiye'nin Göller Bölgesi'nde yer alan ve aynı zamanda 1996 y1lından itibaren Ramsar Sulak Alanı kapsamında korunan Burdur Gölü'nün, geçmişten başlayıp günümüze kadar karasal ortama çıkan, karasal ortamda akarsularla depolanan aluviyal fanlarda gerçekleştirilmiştir. Çalışma alanının sınırları, bu alanda halihazırda var olan diğer göl sistemlerinden de etkilenmiş alanları ayıklamak amacıyla sadece Burdur göl çanağının güncel akaçlama noktalarının yaklaşık sınırı olan $1000 \mathrm{~m}$ yükseklik ile sınırlı tutulmuştur (Şekil 1). Çalışma alanı Isparta ve Burdur İl İdari sınırlarının içerisinde kalan $610.23 \mathrm{~km}^{2}$ lik alanı kapsamaktadır (Şekil 2). Çalışma alanı içerisinde, yaklaşık 950 m'den sonra alüviyal fan arazilerine rastlanılmamış olması, çalışma alanında tanımlanmış olan profillerin yaklaşık $850-950 \mathrm{~m}$ arasındaki yükseklik ile sinırlandırılmasına neden olmuştur (Şekil 3). Burdur Meteoroloji İstasyonundan elde edilen uzun y1llık (1975-2017) iklim verilerine göre, çalışma alanının ortalama sıcaklığı $13.34^{\circ} \mathrm{C}$, ortalama toplam yağış1 $419.01 \mathrm{~mm}$, ortalama toplam yüzey buharlaşması $1202.3 \mathrm{~mm}$ ve ortalama nisbi nemi de \%58.07 olarak bildirilmiştir (Gözükara 2019).

Burdur Gölü'nün de içinde bulunduğu Burdur Havzası, tektonik olarak Fethiye-Burdur fay zonundan etkilenmiş tektonik bir grabendir. Burdur Gölü, Fethiye-Eğirdir Gölü arasında uzanan Güney Batı Anadolu Fay (GBAF) zonu içerisinde yer alır (Karaman 1990). Fay zonu boyunca, sol yönlü oblik normal fay hareketi etkin olmuştur. Kuvaterner devrinin Holosen döneminin başlaması ile iklim değişikliği ve havzadaki tektonik hareketlere bağlı çökmeler sonucunda göl seviyesinde düşüşlerin başladığ 1 belirtilmiştir (Atalay 1977; Roberts ve ark. 2003; Tudryn ve ark. 2013; Atalay 2017).

\subsection{Metot}

\subsubsection{Büro çalışmaları}

Çalışmada alüviyal arazilerdeki profil nokta yerlerinin tespit edilmesinde temel kartografik materyal olarak; Harita Genel Komutanlığı (HGK) tarafindan üretilen 1/25000 ölçekli topografik haritalar, Maden Tetkik Arama Genel Müdürlüğü (MTA) tarafindan üretilen $1 / 25000$ ve 1/100000 ölçekli jeoloji haritaları, Tapu Kadastro Genel Müdürlüğü (TKGM) tarafindan üretilen stereo ortofotolar (30 cm çözünürlüklü) materyal olarak kullanılmıştır. Sayısal veri tabanından tematik haritaların oluşturulması aşamasında ArcGIS 10.2 yazılımından faydalanılmıştır.

\subsubsection{Arazi çalışmaları}

Birinci aşamada belirlenen olası profil noktaları, arazi şartlarında kesinleştirilerek profil çukurları açılmıştır. Araştırma kapsamında alüviyal fanlar üzerinde konumları ve özellikleri Çizelge 1'de gösterilen 12 adet toprak profili açılmış ve bu profillerde 66 farklı horizon tanımlanmıştır. Bu horizonların her birisi Soil Survey Staff (1998) esasları dahilinde morfometrikgenetik yaklaşımla Şenol (2015) tarafından belirtildiği şekliyle tanımlanmıştır. Arazi şartlarında her bir profilde genetik horizon esasına göre yapılan morfolojik tanımlamalarda; horizonların alt 

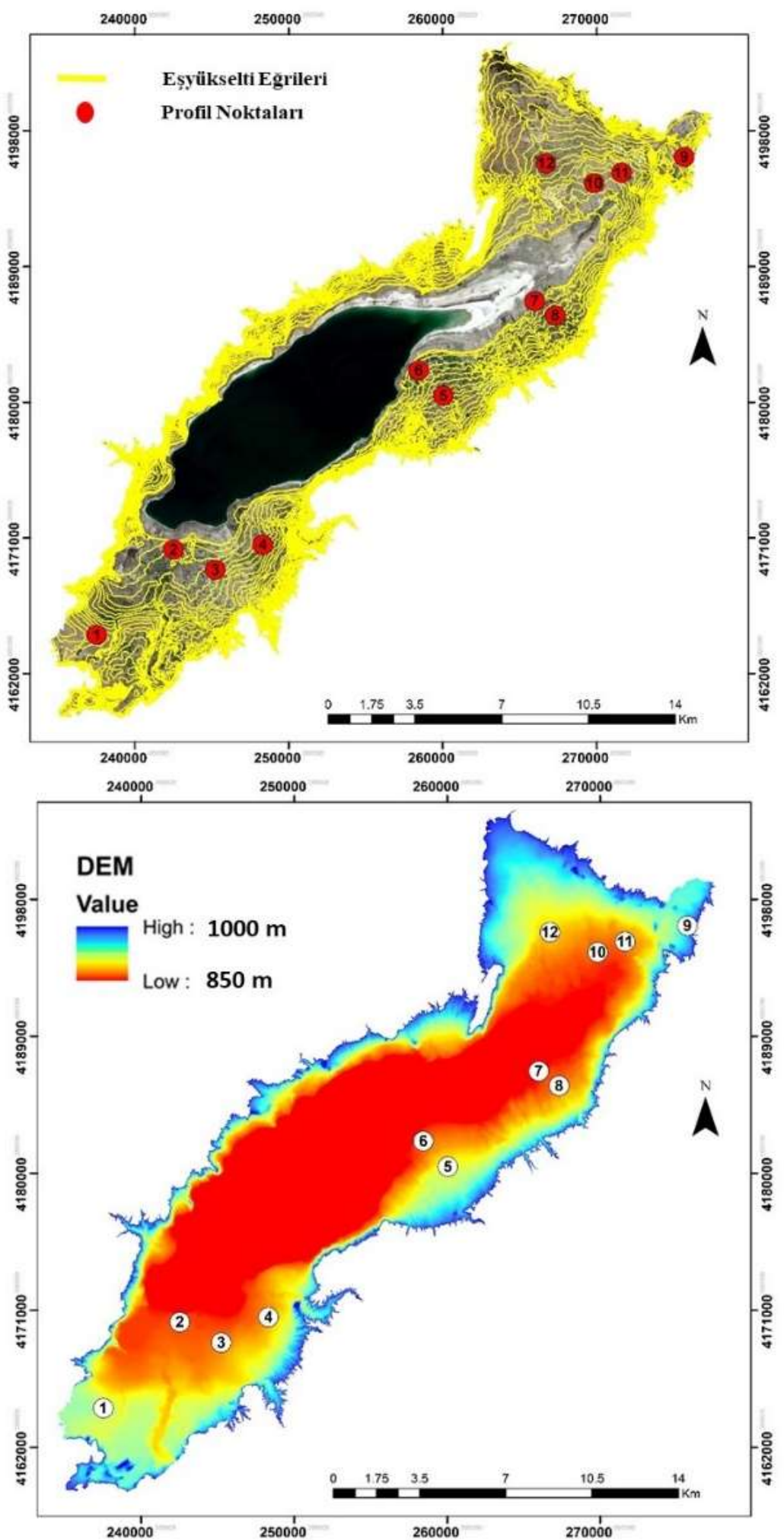

Şekil 1. Çalışma alanının eşyükselti eğrileri (a) ve DEM verileri (b.)

Figure 1. Contour curves of the study area (a) and DEM data (b).

ve üst sınırları, horizonlar arası sınır özellikleri, renk, tekstür, strüktür, kıvam, kireç içeriği, kök dağılımı, taşlılık, gözeneklilik ve diğer özel görünümler (kayma yüzeyleri, kireç birikimleri, kütan, vb.) dikkate alınarak tanımlanmıștır (Hızalan 1969; Soil Survey Staff 1993; Dinç ve Şenol 2013). Morfolojik tanımlamalarda \%10'luk $\mathrm{HCl}$, Munsell renk skalası, şerit metre ve x30, x100 el büyüteci kullanılmıștır (Soil Survey Staff 1993; Dinç ve Şenol 2013). Morfolojik tanımlamaları yapılmış olan her bir horizondan fiziksel ve kimyasal analizlerde kullanılmak amacıyla 66 adet toprak örneği alınmıştır. 

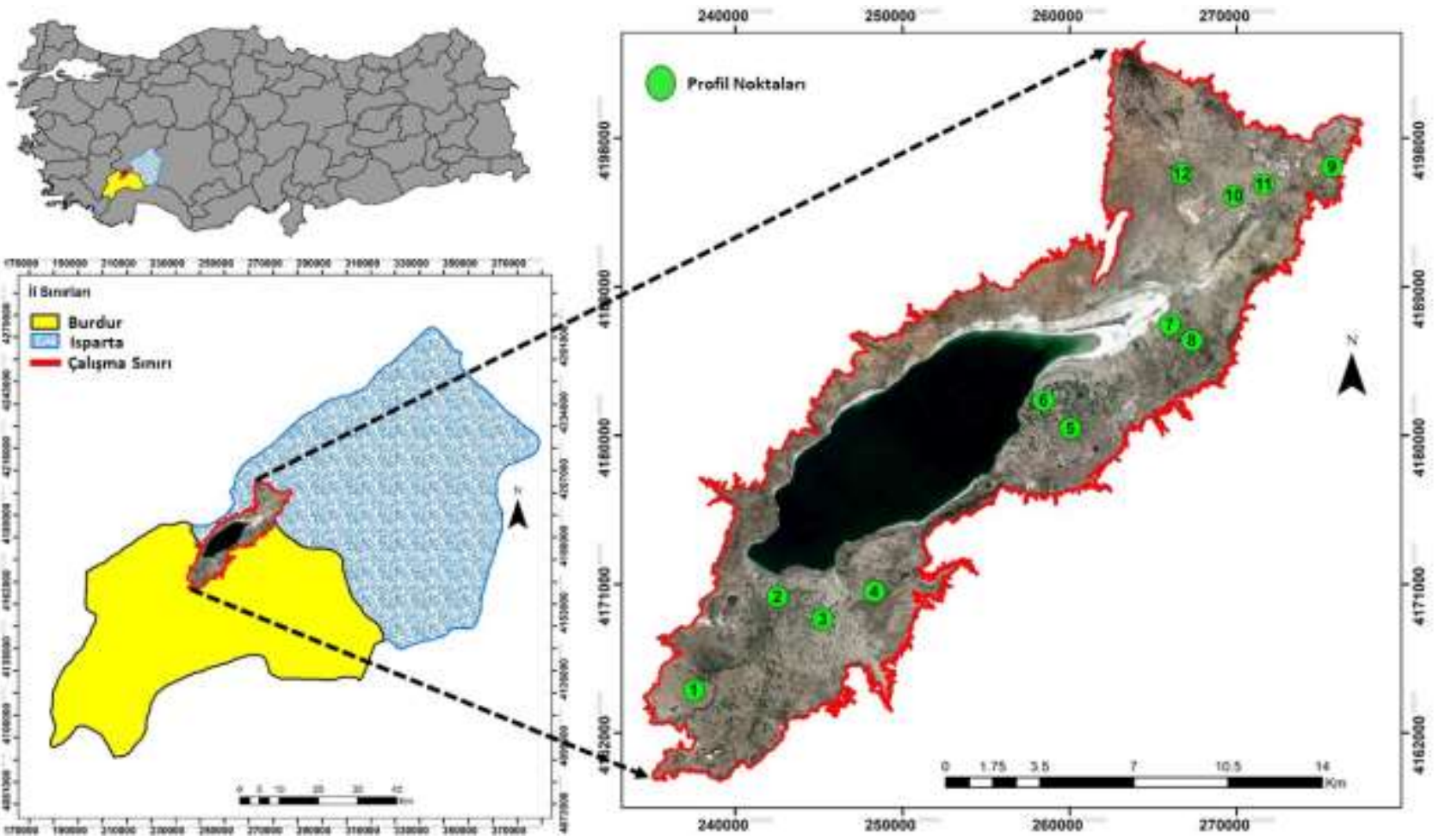

Sekil 2. Çalışma alanının konumu ve profil noktalarının dağllımı.

Figure 2. Location of the study area and distribution of profile points.

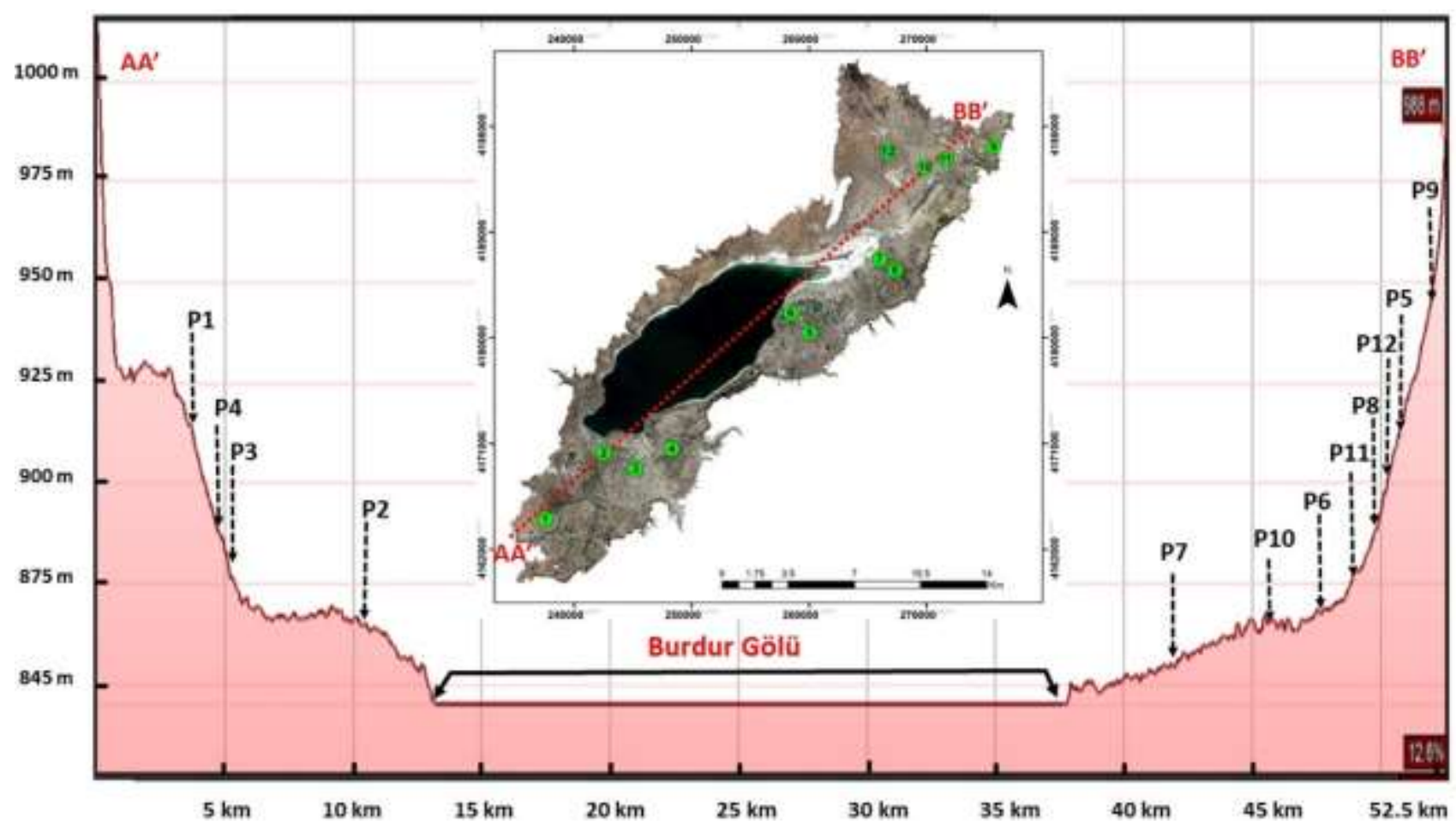

Şekil 3. Toprak profillerinin farklı yükseklik basamaklarına göre dağılımları.

Figure 3. Distribution of soil profiles according to different elevation steps.

\subsubsection{Laboratuvar çalışmaları}

Profillerden genetik horizon esasına göre alınan toprak örnekleri, laboratuvarda analize alınmadan önce oda sıcaklığında hava kuru hale getirildikten sonra 2 mm'lik elekten elenerek analizler için uygun hale getirilmiştir. Toprak örneklerinde, toprak bünyesi (Bouyoucos 1955), organik madde (Black 1965), 1:2.5 toprak-su karışımında $\mathrm{pH}$ ve EC (Jackson 1967), kireç $\left(\mathrm{CaCO}_{3}\right)$ (Evliya 1964), katyon değişim kapasitesi (KDK) (Soil Survey Laboratory Manuals 2004), 
Çizelge 1. Alüviyal fanlar üzerinde gelişen profillerin özellikleri.

Table 1. Properties of profiles developed on alluvial fans.

\begin{tabular}{|c|c|c|c|c|c|}
\hline Profil No & Konum & Yükseklik & Fizyografya & Ana materyal & Arazi Kul. \\
\hline 1 & $37^{\circ} 35^{\prime} 27.38^{\prime \prime K}-30^{\circ} 01^{\prime} 37.57^{\prime \prime D}$ & $920 \mathrm{~m}$ & Alüviyal Fan & Alüviyal & Kuru tarım \\
\hline 2 & $37^{\circ} 38^{\prime} 34.20^{\prime \prime K}-30^{\circ} 04^{\prime} 51.70^{\prime \prime D}$ & $865 \mathrm{~m}$ & Alüviyal Fan & Alüviyal & Kuru tarım \\
\hline 3 & $37^{\circ} 37^{\prime} 54.32^{\prime \prime K}-30^{\circ} 06^{\prime} 45.86^{\prime \prime D}$ & $880 \mathrm{~m}$ & Alüviyal Fan & Alüviyal & Kuru tarım \\
\hline 4 & $37^{\circ} 38^{\prime} 51.77^{\prime \prime K}-30^{\circ} 08^{\prime} 49.80^{\prime \prime D}$ & $881 \mathrm{~m}$ & Alüviyal Fan & Alüviyal & Mera \\
\hline 5 & $37^{\circ} 44^{\prime} 23.16^{\prime \prime K}-30^{\circ} 16^{\prime} 36.23^{\prime \prime D}$ & $906 \mathrm{~m}$ & Alüviyal Fan & Alüviyal & Kuru tarım \\
\hline 6 & $37^{\circ} 45^{\prime} 17.11^{\prime \prime K}-30^{\circ} 15^{\prime} 27.43^{\prime \prime D}$ & $872 \mathrm{~m}$ & Alüviyal Fan & Alüviyal & Kuru tarım \\
\hline 7 & $37^{\circ} 47^{\prime} 52.94 " \mathrm{~K}-30^{\circ} 20^{\prime} 29.92^{\prime \prime D}$ & $854 \mathrm{~m}$ & Alüviyal Fan & Alüviyal & Kuru tarım \\
\hline 8 & $37^{\circ} 47^{\prime} 25.87^{\prime \prime K}-30^{\circ} 21^{\prime} 25.67^{\prime \prime D}$ & $886 \mathrm{~m}$ & Alüviyal Fan & Alüviyal & Kuru tarım \\
\hline 9 & $37^{\circ} 53^{\prime} 10.73^{\prime \prime K}-30^{\circ} 26^{\prime} 57.77^{\prime \prime D}$ & $953 \mathrm{~m}$ & Alüviyal Fan & Alüviyal & Kuru tarım \\
\hline 10 & $37^{\circ} 52^{\prime} 07.50^{\prime \prime K}-30^{\circ} 22^{\prime} 59.33^{\prime \prime D}$ & $868 \mathrm{~m}$ & Alüviyal Fan & Alüviyal & Kuru tarım \\
\hline 11 & $37^{\circ} 52^{\prime} 33.02^{\prime \prime K}-30^{\circ} 24^{\prime} 12.19^{\prime \prime D}$ & $878 \mathrm{~m}$ & Alüviyal Fan & Alüviyal & Kuru tarım \\
\hline 12 & $37^{\circ} 52^{\prime} 48.56^{\prime \prime K}-30^{\circ} 20^{\prime} 50.84^{\prime \prime D}$ & $898 \mathrm{~m}$ & Alüviyal Fan & Alüviyal & Kuru tarım \\
\hline
\end{tabular}

değişebilir katyon (DK) (Kacar 1995) analizleri yapılmıştır. Değişebilir sodyum değerinin diğer değişebilir katyonların toplamına oranlanmasıyla değiş̧ebilir sodyum yüzdesi (ESP) hesaplanmıştır (Bower 1959). Suda çözülebilir klor (Johnson ve Ulrich 1959) suda çözülebilir sülfat (Fox ve ark. 1964), suda çözülebilir karbonat ve bikarbonat (Ayyıldız 1990) analizleri yapılmıştır.

\section{Bulgular ve Tartışma}

Farklı jeolojik devir ve dönemlerde, iklimsel parametreler ve tektonizma sonucunda göl seviyesin azaldığı ortaya çıkan eski göl tabanı arazileri üzerine ise çeşitli büyüklükte mevsimlik/sürekli yüzey suları ve akarsular tarafından taşınarak getirilen farklı nitelik ve nicelikteki malzemelerin depolandığ alanlarda (aluviyal fanlarda) alüviyal depozitler bulunmaktadır. Alüviyal ana materyal üzerinde gelişen toprak profillerinin Burdur Gölü'nün merkezine göre konumları ile deniz seviyesine göre yükseklikleri değerlendirildiğinde; Burdur Gölü'nün güneybatı sahilinde (GBS) Kuvaterner dönemde sudan kurtulmuş alanlarda $920 \mathrm{~m}$ yükseklikte $\mathrm{P} 1,865 \mathrm{~m}$ yükseklikte P2, $880 \mathrm{~m}$ yükseklikte $\mathrm{P} 3$ ve $881 \mathrm{~m}$ yükseklikte $\mathrm{P} 4$, Burdur Gölü'nün doğu sahilindeki (DS) $906 \mathrm{~m}$ yükseklikte P5, $872 \mathrm{~m}$ yükseklikte P6, Burdur Gölü'nün kuzeydoğu sahilinde Kuvaterner dönemde sudan kurtulmuş alanlarda $854 \mathrm{~m}$ yükseklikte $P 7,886$ m yükseklikte $P 8,953$ m yükseklikte $P 9$ ve 868 m yükseklikte P10, $878 \mathrm{~m}$ yükseklikte P11, $898 \mathrm{~m}$ yükseklikte P12 profilleri yer almaktadır (Şekil 3). Görüldüğü üzere alüviyal ana materyal üzerinde gelişim gösteren profillerinde mekansal farklılıklar mevcuttur (Şekil 4). Bu mekansal farklılıklar sonucunda aüviyal ana materyal üzerindeki toprak oluşumu ve gelişiminin toprakların morfolojik, fiziksel ve kimyasal özellikleri üzerine etkileri aşağıda tartışılmıştır.

Alüviyal ana materyal üzerinde oluşan ve gelişen profillerin tamamı A-C horizon dizilimine sahiptir. Budur Gölü'nün güneybatı sahilinde (GBS) bulunan profillerde yaş renk incelendiğinde; $\mathrm{P} 1$ profilinde Ap ve A2 horizonlarında 7.5YR diğer horizonlarda $2.5 \mathrm{Y}, \mathrm{P} 2$ ve $\mathrm{P} 4$ profillerinde yüzey horizonlarında $10 \mathrm{YR}$ diğer horizonlarda ise $2.5 \mathrm{Y}, \mathrm{P} 3$ profilinde ise profilin tamamında $2.5 \mathrm{Y}$ olarak belirlenmiştir. Burdur şehir merkezinin de üzerinde yer aldığı Burdur Gölü'nün doğu sahilindeki (DS) alüviyal fanda bulunan P5 ve P6 profillerinin horizonlarının tamamında yaş renk $2.5 \mathrm{Y}$ olarak belirlenmiştir. Burdur Gölü'nün kuzeydoğu sahilinde (KDS) farklı mekanlarında bulunan P8 ve P12 profillerindeki horizonların tamamında yaş renk $2.5 \mathrm{Y}$ olarak tespit edilirken diğer profillerde ise yaş renk horizonlara göre düzensiz bir dağılım göstermekle birlikte $2.5 \mathrm{Y}, 5 \mathrm{Y}, 7.5 \mathrm{YR}$ ve $10 \mathrm{YR}$ tonlarında değişkenlik göstermektedir (Çizelge 2). Profillerin strüktürleri dayanıklılık, büyüklük ve tip özelliklerine göre değerlendirildiğinde; GBS'de bulunan P1 profilinin A horizonlarında zayıf küçük granüler ve zayıf orta granüler olarak tespit edilirken P2, P3 ve P4 profillerin A horizonlarında orta orta yarı köşeli blok ve kuvvetli orta yarı köşeli blok olarak belirlenmiştir. GBS'deki strüktür oluşumu; P1'de $40 \mathrm{~cm}, \mathrm{P} 2$ 'de $63 \mathrm{~cm}, \mathrm{P} 13$ 'da $25 \mathrm{~cm}$ ve P4'de $15 \mathrm{~cm}$ sinırlı da olsa strüktürel oluşumu tespit edilmiştir. GBS'de bulunan P1 profilinin C horizonlarında teksel strüktür tespit edilirken diğer profillerin $\mathrm{C}$ horizonlarında masif strüktür belirlenmiştir. DS'de bulunan P5 ve P6 profillerinde strüktür Ap ve A2 horizonlarında zayıf küçük yarı köşeli blok, orta orta yarı köşeli blok ve zayıf orta yarı köşeli blok, $\mathrm{C}$ horizonlarının tamamında ise masif olarak tespit edilmiştir. DS'deki strüktürel gelişim; P5'de $35 \mathrm{~cm}$ ve P6'da $27 \mathrm{~cm}$ ile sınırlı da olsa strüktürel gelişim tespit edilmiştir. KDS'de bulunan $\mathrm{P} 7, \mathrm{P} 8, \mathrm{P} 10$ ve $\mathrm{P} 12$ profillerinin yüzey horizonlarında orta orta yarı köşeli blok, P9 profilinin Ap ve A2 horizonlarında orta orta granüler ve zayıf küçük yarı köşeli blok ve P11 profilinde Ap ve A2 horizonlarında zayıf küçük yarı köşeli blok strüktür tespit edilmiştir. P9 profilinin C horizonlarında teksel olarak belirlenen strüktür, diğer KDS'de bulunan profillerin $\mathrm{C}$ horizonlarının tamamında masif tespit edilmiştir. KDS'deki strüktürel oluşum; P7'de $40 \mathrm{~cm}$, P8'de 45 $\mathrm{cm}$, P9'da $35 \mathrm{~cm}, \mathrm{P} 10$ 'da $41 \mathrm{~cm}, \mathrm{P} 11$ 'de $47 \mathrm{~cm}$ ve P12'de 38 cm olarak tespit edilmiştir. Genel olarak DS ve KDS de bulunan profillerde göle yaklaştıkça yüzeyden alt horizonlara doğru strüktürel oluşumda azalma belirlenirken, GBS de bulunan profillerde ise göle yaklaştıkça yüzeyden alt horizonlara doğru strüktürel oluşumda düzensiz gelişim belirlenmiştir (Çizelge 2). Profillerdeki özel görünümler değerlendirildiğinde; GBS'de bulunan P1 profilinin horizonlarının tamamında yüzey horizonlarında $0.2-0.4 \mathrm{~cm}$ çaplı yuvarlak yoğun çakı1 parçacıkları gözlemlenirken $C$ horizonundan itibaren 1-2 cm çaplı yuvarlak çok yoğun çakıl parçacıkları tespit edilmiştir. KDS'de bulunan P7 ve P9 profillerinin horizonlarının tamamında üst horizonlardan alt horizonlara doğru yoğunluğu artmakla birlikte $0.1-0.2 \mathrm{~cm}$ çapında yuvarlak çakı1 parçacıkları tespit edilmiştir. GBS'de bulunan $\mathrm{P} 2$ profilinin $3 \mathrm{C}$ horizonunda az yoğun pas lekesi ile $5 \mathrm{C}$ ve $6 \mathrm{C}$ horizonlarında çok yoğun pas lekesi ve P4 profilinin $4 \mathrm{C}$ horizonunda orta yoğun pas lekesi ve $85 \mathrm{~cm}$ 'den sonra taban suyu gözlemlenmiştir. Profillerin tamamının horizonları belirgin düz sınıra sahiptir (Çizelge 2). 

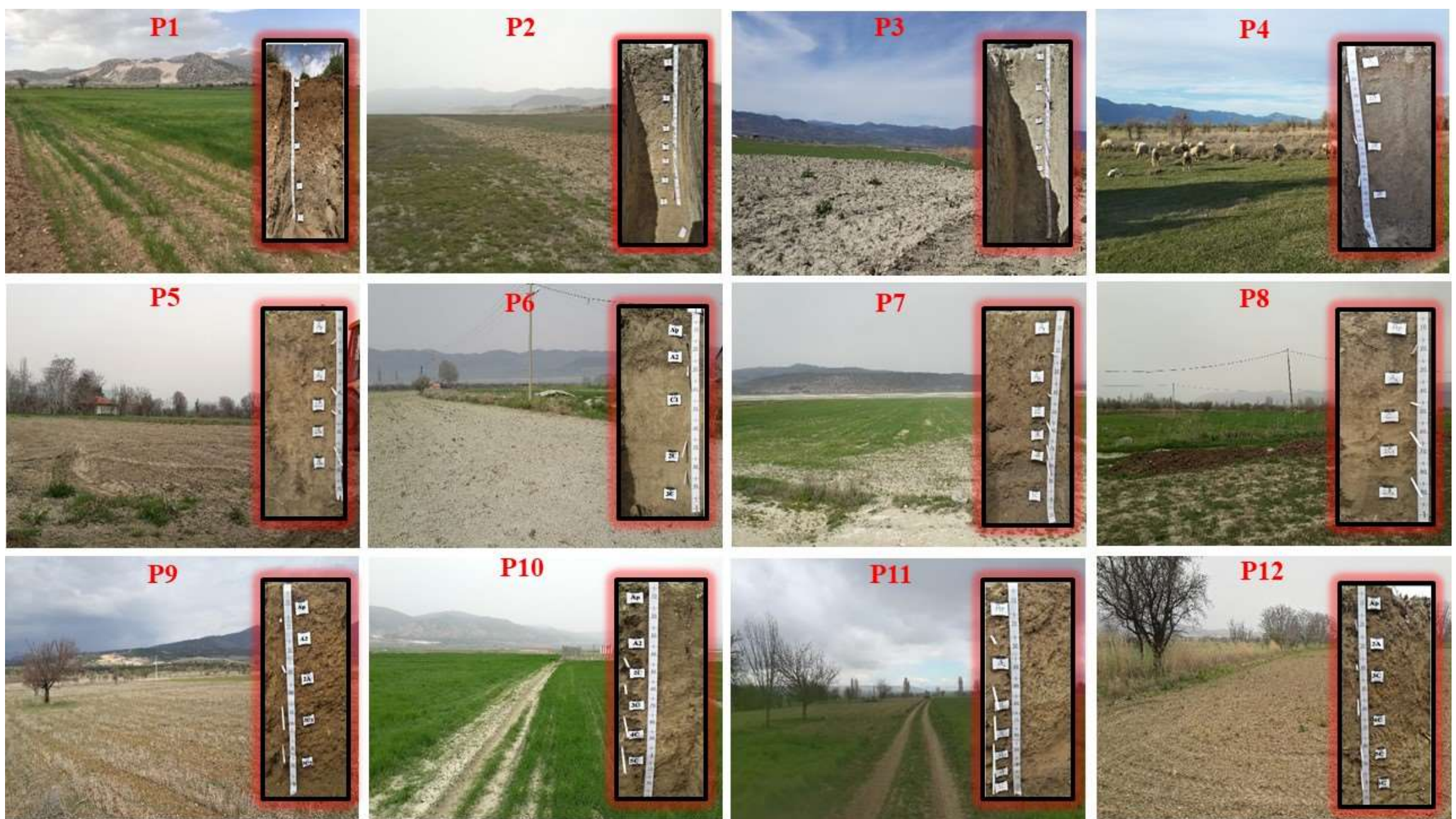

Sekil 4. Çalışma alanı içerisinde toprak profillerinin tanımlandığı arazilerin görüntüsü ve horizonlar. Figure 4. The view of the lands in which soil profiles are defined within the study area and horizons. 
Çizelge 2. Profillerin morfolojik, fiziksel ve kimyasal özellikleri.

Table 2. Morphological, physical and chemical properties of profiles.

\begin{tabular}{|c|c|c|c|c|c|c|c|c|c|c|}
\hline Profil Numarası & Horizon & Derinlik $(\mathrm{cm})$ & Renk (Yaş) & Strüktür & Kireç (\%) & Organik Mad. (\%) & $\operatorname{Kum}(\%)$ & Silt (\%) & Kil (\%) & Tekstür Sınıfı \\
\hline \multirow{5}{*}{$\mathrm{P} 1$} & Ap & $0-20$ & 7.5YR 4/4 & ZKG & 17.52 & 1.30 & 74.69 & 13.43 & 11.88 & SL \\
\hline & $\mathrm{A} 2$ & $20-40$ & $7.5 Y R$ 4/4 & $\mathrm{ZOG}$ & 18.20 & 0.74 & 78.69 & 8.50 & 12.81 & SL \\
\hline & $\mathrm{C}$ & $40-90$ & $2.5 \mathrm{Y} 6 / 3$ & Teksel & 25.55 & 0.32 & 82.69 & 6.50 & 10.81 & LS \\
\hline & $2 \mathrm{C}$ & $90-120$ & $2.5 \mathrm{Y} 7 / 2$ & Teksel & 28.77 & 0.33 & 90.69 & 4.58 & 4.74 & $\mathrm{~S}$ \\
\hline & $3 \mathrm{C}$ & $120-140$ & $2.5 \mathrm{Y} 7 / 2$ & Teksel & 31.34 & 0.32 & 84.69 & 4.50 & 10.81 & LS \\
\hline \multirow{7}{*}{$\mathrm{P} 2$} & $\mathrm{Ap}$ & $0-28$ & $10 Y R$ 5/2 & OOYKB & 29.73 & 2.34 & 9.05 & 39.57 & 51.38 & $\mathrm{C}$ \\
\hline & $\mathrm{AC}$ & $28-63$ & $2.5 Y 5 / 3$ & KOYKB & 31.66 & 0.92 & 5.12 & 40.64 & 54.24 & $\mathrm{C}$ \\
\hline & $2 \mathrm{C}$ & $63-81$ & $2.5 Y 5 / 4$ & Masif & 36.00 & 0.24 & 25.26 & 42.78 & 31.95 & $\mathrm{CL}$ \\
\hline & $3 \mathrm{C}$ & $81-94$ & $2.5 \mathrm{Y} 6 / 3$ & Masif & 36.80 & 0.32 & 7.26 & 46.86 & 45.88 & $\mathrm{SiC}$ \\
\hline & $4 \mathrm{C}$ & $94-110$ & $2.5 \mathrm{Y} 6 / 2$ & Masif & 41.54 & 1.58 & 65.12 & 23.93 & 10.95 & SL \\
\hline & $5 \mathrm{C}$ & $110-132$ & $2.5 Y 5 / 3$ & Masif & 34.39 & 0.29 & 13.26 & 46.86 & 39.88 & SiCL \\
\hline & $6 \mathrm{C}$ & $132+$ & $2.5 \mathrm{Y} 6 / 2$ & Masif & 43.63 & 0.17 & 60.34 & 28.86 & 10.81 & $\mathrm{SL}$ \\
\hline \multirow{5}{*}{ P3 } & $\mathrm{Ap}$ & $0-25$ & $2.5 \mathrm{Y} 5 / 3$ & OOYKB & 36.33 & 2.47 & 4.12 & 34.14 & 61.74 & $\mathrm{C}$ \\
\hline & $\mathrm{AC}$ & $25-40$ & $2.5 Y 5 / 3$ & Masif & 42.80 & 1.10 & 3.82 & 44.07 & 52.10 & $\mathrm{SiC}$ \\
\hline & $2 \mathrm{C}$ & $40-84$ & $2.5 Y 7 / 3$ & Masif & 43.24 & 0.67 & 2.98 & 35.28 & 61.74 & $\mathrm{C}$ \\
\hline & $3 C$ & $84-106$ & $2.5 \mathrm{Y} 7 / 2$ & Masif & 42.44 & 1.32 & 0.05 & 40.14 & 59.82 & $\mathrm{C}$ \\
\hline & $4 \mathrm{C}$ & $106+$ & $2.5 \mathrm{Y} 7 / 3$ & Masif & 43.32 & 1.71 & 1.05 & 40.06 & 58.89 & $\mathrm{C}$ \\
\hline \multirow{4}{*}{$\mathrm{P} 4$} & A1 & $0-15$ & 10YR 5/2 & OOYKB & 17.03 & 9.40 & 32.19 & 57.14 & 10.66 & SiL \\
\hline & $2 \mathrm{C}$ & $15-54$ & $2.5 Y 6 / 3$ & Masif & 28.12 & 1.31 & 19.48 & 35.14 & 45.38 & $\mathrm{C}$ \\
\hline & $3 \mathrm{C}$ & $54-85$ & $2.5 \mathrm{Y} 6 / 3$ & Masif & 28.85 & 0.64 & 13.48 & 37.00 & 48.52 & $\mathrm{C}$ \\
\hline & $4 \mathrm{C}$ & $85+$ & $2.5 \mathrm{Y} 5 / 3$ & Masif & 30.05 & 0.60 & 19.48 & 37.14 & 43.38 & $\mathrm{C}$ \\
\hline \multirow{5}{*}{ P5 } & Ap & $0-15$ & $2.5 \mathrm{Y} 5 / 3$ & ZKYKB & 29.22 & 3.89 & 24.55 & 42.86 & 32.59 & $\mathrm{CL}$ \\
\hline & $\mathrm{A} 2$ & $15-35$ & $2.5 \mathrm{Y} 6 / 3$ & OOYKB & 32.27 & 2.54 & 27.70 & 40.86 & 31.45 & CL \\
\hline & $2 \mathrm{C} 1$ & $34-47$ & $2.5 \mathrm{Y} 6 / 3$ & Masif & 35.40 & 1.73 & 19.55 & 37.07 & 43.38 & $\mathrm{C}$ \\
\hline & $2 \mathrm{C} 2$ & $47-67$ & $2.5 \mathrm{Y} 6 / 3$ & Masif & 39.41 & 1.98 & 17.70 & 39.40 & 42.90 & $\mathrm{C}$ \\
\hline & $2 \mathrm{C} 3$ & $67+$ & $2.5 \mathrm{Y} 5 / 3$ & Masif & 39.33 & 2.17 & 21.34 & 36.07 & 42.59 & $\mathrm{C}$ \\
\hline \multirow{5}{*}{ P6 } & Ap & $0-15$ & $2.5 \mathrm{Y} 6 / 3$ & ZOYKB & 39.37 & 3.26 & 7.62 & 39.86 & 52.52 & $\mathrm{C}$ \\
\hline & $\mathrm{A} 2$ & $15-27$ & $2.5 \mathrm{Y} 6 / 2$ & ZOYKB & 40.09 & 2.28 & 7.62 & 35.78 & 56.59 & $\mathrm{C}$ \\
\hline & $\mathrm{C}$ & $27-65$ & $2.5 \mathrm{Y} 7 / 3$ & Masif & 46.48 & 1.15 & 2.62 & 42.78 & 54.59 & $\mathrm{SiC}$ \\
\hline & $2 \mathrm{C}$ & $65-81$ & $2.5 \mathrm{Y} 7 / 2$ & Masif & 36.12 & 0.97 & 45.62 & 29.71 & 24.66 & $\mathrm{~L}$ \\
\hline & $3 \mathrm{C}$ & $81+$ & $2.5 \mathrm{Y} 7 / 2$ & Masif & 40.58 & 0.78 & 23.70 & 46.78 & 29.52 & $\mathrm{CL}$ \\
\hline \multirow{6}{*}{ P7 } & Ap & $0-20$ & 10YR 5/2 & ZOYKB & 19.39 & 0.72 & 40.06 & 35.78 & 24.16 & $\mathrm{~L}$ \\
\hline & $\mathrm{A} 2$ & $20-40$ & $10 Y R$ 5/3 & OOYKB & 17.93 & 0.59 & 33.42 & 39.35 & 27.23 & $\mathrm{~L}$ \\
\hline & $2 \mathrm{C}$ & $40-55$ & $2.5 \mathrm{Y} 5 / 2$ & Masif & 17.44 & 0.75 & 74.49 & 11.21 & 14.30 & SL \\
\hline & $3 C$ & $55-67$ & $2.5 \mathrm{Y} 4 / 2$ & Masif & 18.82 & 0.45 & 76.49 & 15.21 & 8.30 & SL \\
\hline & $4 \mathrm{C}$ & $67-77$ & $2.5 Y 5 / 3$ & Masif & 19.72 & 0.24 & 48.42 & 37.21 & 14.38 & $\mathrm{~L}$ \\
\hline & $5 \mathrm{C}$ & $77+$ & $2.5 \mathrm{Y} 4 / 3$ & Masif & 15.98 & 0.54 & 86.56 & 7.06 & 6.38 & LS \\
\hline \multirow{5}{*}{ P8 } & $\mathrm{Ap}$ & $0-21$ & $2.5 \mathrm{Y} 4 / 3$ & OOYKB & 22.56 & 3.18 & 29.41 & 40.00 & 30.59 & CL \\
\hline & $\mathrm{A} 2$ & $21-45$ & $2.5 \mathrm{Y} 4 / 4$ & OOYKB & 21.83 & 2.37 & 22.41 & 44.14 & 33.45 & $\mathrm{CL}$ \\
\hline & $\mathrm{C}$ & $45-61$ & $2.5 Y 5 / 3$ & Masif & 20.61 & 0.86 & 11.77 & 53.00 & 35.23 & SiCL \\
\hline & $2 \mathrm{C} 1$ & $61-84$ & $2.5 Y 5 / 4$ & Masif & 19.55 & 0.84 & 14.06 & 49.64 & 36.30 & $\mathrm{SiCL}$ \\
\hline & $2 \mathrm{C} 2$ & $84+$ & $2.5 Y 5 / 3$ & Masif & 21.42 & 0.75 & 10.27 & 50.57 & 39.16 & SiCL \\
\hline \multirow{5}{*}{ P9 } & Ap & $0-15$ & $2.5 \mathrm{Y} 5 / 4$ & OOG & 25.46 & 2.23 & 36.06 & 32.63 & 31.31 & $\mathrm{CL}$ \\
\hline & A2 & $15-35$ & 10YR 5/4 & ZKYKB & 25.62 & 2.07 & 34.98 & 31.63 & 33.38 & $\mathrm{CL}$ \\
\hline & $2 \mathrm{~A}$ & $35-56$ & 10YR 6/3 & Teksel & 27.16 & 1.47 & 53.13 & 23.56 & 23.31 & SCL \\
\hline & $3 C 1$ & $56-79$ & 10YR 5/4 & Teksel & 32.09 & 0.62 & 67.62 & 16.85 & 15.53 & SL \\
\hline & $3 \mathrm{C} 2$ & $79+$ & $2.5 Y 5 / 4$ & Teksel & 34.51 & 0.48 & 75.84 & 11.78 & 12.38 & SL \\
\hline \multirow{6}{*}{ P10 } & $\mathrm{Ap}$ & $0-17$ & $2.5 Y 5 / 3$ & OOYKB & 27.99 & 1.13 & 1.41 & 35.72 & 62.87 & $\mathrm{C}$ \\
\hline & $\mathrm{A} 2$ & $17-41$ & $2.5 Y 5 / 3$ & OOYKB & 25.98 & 1.01 & 1.77 & 32.36 & 65.87 & $\mathrm{C}$ \\
\hline & $2 \mathrm{C}$ & $41-56$ & $5 Y 5 / 3$ & Masif & 25.26 & 1.78 & 0.77 & 28.58 & 70.66 & $\mathrm{C}$ \\
\hline & $3 C$ & $56-75$ & $5 Y 6 / 2$ & Masif & 25.90 & 1.92 & 1.77 & 28.29 & 69.94 & $\mathrm{C}$ \\
\hline & $4 \mathrm{C}$ & $75-92$ & $5 Y 6 / 3$ & Masif & 29.44 & 2.08 & 3.77 & 33.29 & 62.94 & $\mathrm{C}$ \\
\hline & $5 \mathrm{C}$ & $92+$ & $5 Y 5 / 3$ & Masif & 34.18 & 0.77 & 9.98 & 46.07 & 43.94 & $\mathrm{SiC}$ \\
\hline & $\mathrm{Ap}$ & $0-23$ & 10YR 5/3 & ZKYKB & 31.60 & 1.19 & 11.41 & 34.14 & 54.46 & $\mathrm{C}$ \\
\hline & $\mathrm{A} 2$ & $23-47$ & $2.5 Y 5 / 4$ & ZKYKB & 32.41 & 1.40 & 9.62 & 38.92 & 51.46 & $\mathrm{C}$ \\
\hline & $2 \mathrm{C}$ & $47-63$ & $2.5 \mathrm{Y} 6 / 3$ & Masif & 31.52 & 1.03 & 3.62 & 37.78 & 58.60 & $\mathrm{C}$ \\
\hline $\mathrm{P} 11$ & $3 \mathrm{C} 1$ & $63-81$ & $2.5 Y 5 / 4$ & Masif & 32.01 & 1.05 & 1.62 & 36.70 & 61.67 & $\mathrm{C}$ \\
\hline & $3 \mathrm{C} 2$ & $81-93$ & $2.5 \mathrm{Y} 6 / 3$ & Masif & 32.02 & 1.27 & 0.48 & 36.99 & 62.53 & $\mathrm{C}$ \\
\hline & $4 \mathrm{C}$ & $93-118$ & $2.5 Y 5 / 3$ & Masif & 32.61 & 0.65 & 10.48 & 57.06 & 32.46 & SiCL \\
\hline & $5 \mathrm{C}$ & $118+$ & $2.5 Y 5 / 4$ & Masif & 39.32 & 0.70 & 24.26 & 37.99 & 37.74 & CL \\
\hline & Ap & $0-21$ & $2.5 Y 5 / 3$ & OOYKB & 33.70 & 2.43 & 14.91 & 46.86 & 38.23 & SiCL \\
\hline & $2 \mathrm{~A}$ & $21-38$ & $2.5 Y 6 / 3$ & OOYKB & 36.92 & 1.55 & 7.77 & 52.00 & 40.23 & $\mathrm{SiC}$ \\
\hline & $3 C$ & $38-55$ & $2.5 \mathrm{Y} 6 / 4$ & Masif & 41.87 & 2.88 & 32.06 & 43.86 & 24.09 & $\mathrm{~L}$ \\
\hline $\mathrm{P} 12$ & $4 \mathrm{C}$ & $55-79$ & $2.5 Y 7 / 3$ & Masif & 37.18 & 1.99 & 1.77 & 51.78 & 46.45 & $\mathrm{SiC}$ \\
\hline & $5 \mathrm{C}$ & $79-93$ & $2.5 Y 7 / 3$ & Masif & 39.36 & 2.19 & 14.91 & 46.71 & 38.38 & $\mathrm{SiCL}$ \\
\hline & $6 \mathrm{C}$ & $93+$ & $2.5 \mathrm{Y} 6 / 3$ & Masif & 40.41 & 2.23 & 52.70 & 26.86 & 20.45 & SCL \\
\hline
\end{tabular}


Profillerin kireç içerikleri değerlendirildiğinde; GBS'de bulunan profillerin horizonlarının tamamından çok yüksek kireç içeriğiyle birlikte üst horizonlardan alt horizonlara doğru kireç içeriğinin artış eğilimde olduğu tespit edilmiştir. GBS'de bulunan profiller arasında en fazla kireç içeriği \%29.73-43.63 arasında değişen değer ile P2 profilde tespit edilmiştir. DS'de bulunan P5 ve P6 profillerinin horizonlarının tamamı çok yüksek kireçli olarak tespit edilmiştir. En fazla kireç içeriği ise \%36.12-46.48 arasında değişen değer ile P6 profilinde belirlenmiştir. KDS'de bulunan P7ve P8 profillerinde kireç içeriği üst horizonlardan alt horizonlara doğru azalma eğilimindeyken diğer profillerde ise artma eğilimindedir. KDS'de bulunan profiller arasında en fazla kireç içeriği \%33.70-41.87 değişim aralığı ile $\mathrm{P} 12$ profilinde tespit edilmiştir. GBS, DS ve KDS'de bulunan profiller arasında en fazla kireç içeriğine sahip olan profilin DS'de bulunan P6 profili olduğu tespit edilmiştir (Çizelge 2). Profillerin organik madde içerikleri değerlendirildiğinde; GBS'de bulunan profiller arasında en fazla organik madde içeriği \%0.60-9.40 arasındaki değişim aralığı ile P4 profilinde tespit edilmiştir. P4 profilinin A1 horizonu üzerinde doğal çayır bitki örtüsü ile kaplı olmasından dolayı organik madde içeriğinin yüksekliği sadece yüzey horizonu ile sınırlı kalmıştır. Horizonlardaki organik madde içeriğindeki genel ortalama bakıldığında ise \%0.67-2.47 arasında değişen organik madde içeriği ile P3 profilinin diğer profillere göre daha fazla organik maddeye sahip olduğu tespit edilmiştir. DS'de bulunan P5 ve P6 profilleri arasında en fazla organik madde içeriği \%1.73-3.89 arasında değişen değer ile P5 profilinde belirlenmiştir. KDS'de bulunan profiller arasında en fazla organik madde içeriği \%0.75-3.18 arasında değişim aralığı ile P8 profilinde tespit edilmiştir. Profiller arasında en düşük organik madde içeriği \%0.24-0.72 arasındaki değerler ile P7 profilinde belirlenmiştir. Profillerin tamamında organik madde miktarı üst horizonlardan alt horizonlara doğru azalma eğilimindedir. GBS, DS ve KDS'de bulunan profiller arasında en fazla organik madde içeriğine sahip olan profilin GBS'de bulunan P4 profili olduğu tespit edilmiştir (Çizelge 2).

GBS'de bulunan profiller arasında en az kil içeriği \%4.7412.81arasında değișen değer ile P1 profilinde, en fazla kil içeriği ise \%52.10-61.74 arasında değişen değer ile P3 profilinde tespit edilmiştir. $\mathrm{P} 3$ ve $\mathrm{P} 4$ profillerinin horizonlarının neredeyse tamamında tekstür kil olarak tespit edilmiştir. DS'deki alüviyal fanın alt zonunda bulunan P6 profilindeki kil miktarı \%24.66-56.59 arasında değişirken orta zonda bulunan P5 profilinde \%31.45-43.38 arasında değiştiği tespit edilmiştir. KDS'de bulunan profillerden $\mathrm{P} 10$ ve P11 profilleri sirasiyla \%43.96-70.66 ve \%32.46-62.53 arasında değişen kil miktarı ile diğer profillerden daha fazla kil içeriğine sahip oldukları belirlenmiştir. $\mathrm{Bu}$ yüksek kil içeriğinde, çalışma alanının özellikle kuzey ve kuzeydoğu istikametinden Burdur gölüne doğru akmakta olan birkaç mevsimlik derenin eski jeolojik süreçlerdeki faaliyetleri kapsamında farklı mekanlardan getirmiş oldukları materyallerin söz konusu derelerin materyal depolama güzergahlarının (boylamasına dereceleme alanlarının) neredeyse son kısımlarında olması etkili olmuştur. KDS'de bulunan diğer profillerde ise farklı jeolojik devir ve dönemlerde akarsular tarafindan taşınan materyallerin faklılığına bağlı olarak kumlu tın, tınlı kum, siltli kil, siltli killi tın, tın, siltli kil, kumlu killi tın ve kil gibi çok farklı tekstürler belirlenmiştir (Çizelge 2). Profillerdeki pH değerleri, GBS'de bulunan profiller arasında en yüksek $\mathrm{pH}$ değeri göl kıyısına en yakın olan P2 profilinin horizonlarında 8.04-8.36 değerleri ile tespit edilmiştir. DS'de bulunan P5 ve P6 profillerinde sırasıyla 7.848.17 ve 7.97-8.18 arasında değișirken KDS'de bulunan profillerde ise P7'de 7.91-8.94, P8'de 7.93-8.28 ve P10'da 7.948.37 değerleri ile diğer çevresindeki profillerden daha yüksek değerlere ulaştı̆̆ tespit edilmiştir. Genel olarak GBS, DS ve KDS'de bulunan profillerde göle yaklaştıkça $\mathrm{pH}$ değerlerinde artış tespit edilmiştir. Beyhan ve ark. (2007) tarafından yapılan çalışmada, Burdur Gölü suyunun mevsimsel yağış, buharlaşma, göle su taşıyan mevsimlik/sürekli akarsuların artan veya azalan su debileri ve konumsal farklılıklara göre değişiklik göstermekle birlikte $\mathrm{pH}$ değerinin 8.4-9.3 arasında değiştiğini belirtmişlerdir. Beyhan ve ark. (2007) bu bulguları doğrultusunda, alüviyal fan üzerinde gelişen topraklarımızın $\mathrm{pH}$ değerlerinin göle yaklaştıkça artış göstermesinde toprakların genetiksel özellikleri itibariyle pH'larının yüksek olması ile birlikte göl suyundan da etkilendikleri belirlenmiştir (Çizelge 3).

Alüviyal ana materyal üzerinde gelişen profillerin genelinde EC değerleri düşük seviyelerde tespit edilmiştir. GBS'de en yüksek değer 0.73-2.93 $\mathrm{dS} \mathrm{m}{ }^{-1}$ değişim aralığı ile P4 profilinde, DS'de en fazla değer 0.40-0.54 $\mathrm{dS} \mathrm{m}^{-1}$ değişim aralığı ile P5'de, KDS'de en fazla değer ise $0.25-0.46 \mathrm{dS} \mathrm{m}^{-1}$ değişim aralığı ile P11 profilinde tespit edilmiştir. Aluviyal yelpazeler üzerinde gelișen profiller arasında en yüksek EC değeri GBS'de bulunan P4 profilinde belirlenmiştir. Genel olarak GBS, DS ve KDS'de bulunan profillerde göle yaklaştıkça EC değerlerinde artış tespit edilmiştir. Beyhan ve ark. (2007) tarafından yapılan çalışmada, Burdur Gölü suyunun mevsimsel yağış, buharlaşma, göle su taşıyan mevsimlik/sürekli akarsuların artan veya azalan su debilerine ve mekansal farklılığa göre değişiklik göstermekle birlikte EC değerinin 11.50-29.88 $\mathrm{dS} \mathrm{m}^{-1}$ arasında değiştiğini belirtmişlerdir. Beyhan ve ark. (2007) bu bulguları doğrultusunda, eski göl tabanı üzerinde gelişen topraklarımızın EC değerlerinin göle yaklaş̧ıkça artış göstermesinde toprakların genetiksel özellikleri ile birlikte göl suyunun yoğun tuzluluğundan da etkilendikleri belirlenmiştir (Çizelge 3).

Eriyebilir anyonların GBS'deki konsantrasyonları değerlendirildiğinde; en fazla $\mathrm{CO}_{3}{ }^{-2}$ ve $\mathrm{HCO}_{3}{ }^{-}$konsantrasyonları

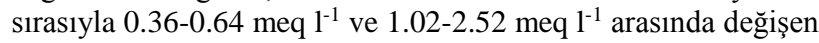
değerler ile $\mathrm{P} 2$ profilinde, en fazla $\mathrm{Cl}^{-}$konsantrasyonu 2.40-7.80 meq $1^{-1}$ arasında değişen değer ile $\mathrm{P} 3$ profilinde ve en fazla $\mathrm{SO}_{4}^{-2}$ konsantrasyonu 5.13-30.97 meq $^{-1}$ arasında değișen değer ile en fazla P4 profilinde tespit etmiştir. Eriyebilir anyonlar profillerde genellikle üst horizonlardan alt horizonlara doğru azalma eğilimindedir. DS'de en fazla $\mathrm{HCO}_{3}{ }^{-}$ve $\mathrm{Cl}^{-}$

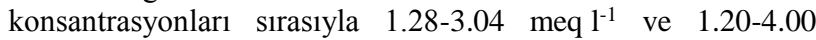
meq $1^{-1}$ arasında değişen değer ile $\mathrm{P} 5$ profilinde, en fazla $\mathrm{CO}_{3}{ }^{-2}$ ve $\mathrm{SO}_{4}^{-}$konsantrasyonları sirasiyla $0.16-0.68 \mathrm{meq} \mathrm{l}^{-1}$ ve 1.01-3.47 meq $\mathrm{l}^{-1}$ arasında değişen değerleri ile P6 profilinde tespit edilmiştir. Profillerde üst horizonlardan alt horizonlara doğru $\mathrm{CO}_{3}^{-2}$ ve $\mathrm{Cl}$ konsantrasyonları artma eğilimindeyken $\mathrm{HCO}_{3}{ }^{-}$ve $\mathrm{SO}_{4}^{-2}$ konsantrasyonları azalma eğilimindedir. KDS'de bulunan profiller arasinda en fazla $\mathrm{CO}_{3}^{-2}$ konsantrasyonu 0.12-0.56 meq $\mathrm{l}^{-1}$ arasında değișen değer ile P12 profilinde $\mathrm{HCO}_{3}{ }^{-}, \mathrm{Cl}^{-}$ve $\mathrm{SO}_{4}^{-2}$ konsantrasyonlarında sirasiyla $1.18-2.50$ meq $^{-1}$, $1.50-3.20$ meq $^{1^{-1}}$ ve 3.63-6.83 meq $1^{-1}$ arasında değişen değerler ile P8 profilinde olduğu tespit edilmiştir. Beyhan ve ark. (2007) tarafından yapılan çalışmada, Burdur Gölü suyunun karbonat, bikarbonat, klorür ve sülfat anyonları kapsamında oldukça zengin olduğunu tespit etmişlerdir. Aynı zamanda göl seviyesindeki azalmalar sonucunda azalan su miktarına bağlı olarak bu anyonların konsantrasyonlarında da artış olduğunu belirtmişlerdir. Araştırmamızda da göle yaklaştıkça profillerdeki karbonat, bikarbonat, klor ve sülfat konsantrasyonlarında önemli artışlar 
Çizelge 3. Profillerin kimyasal özellikleri.

Table 3. Chemical properties of profiles.

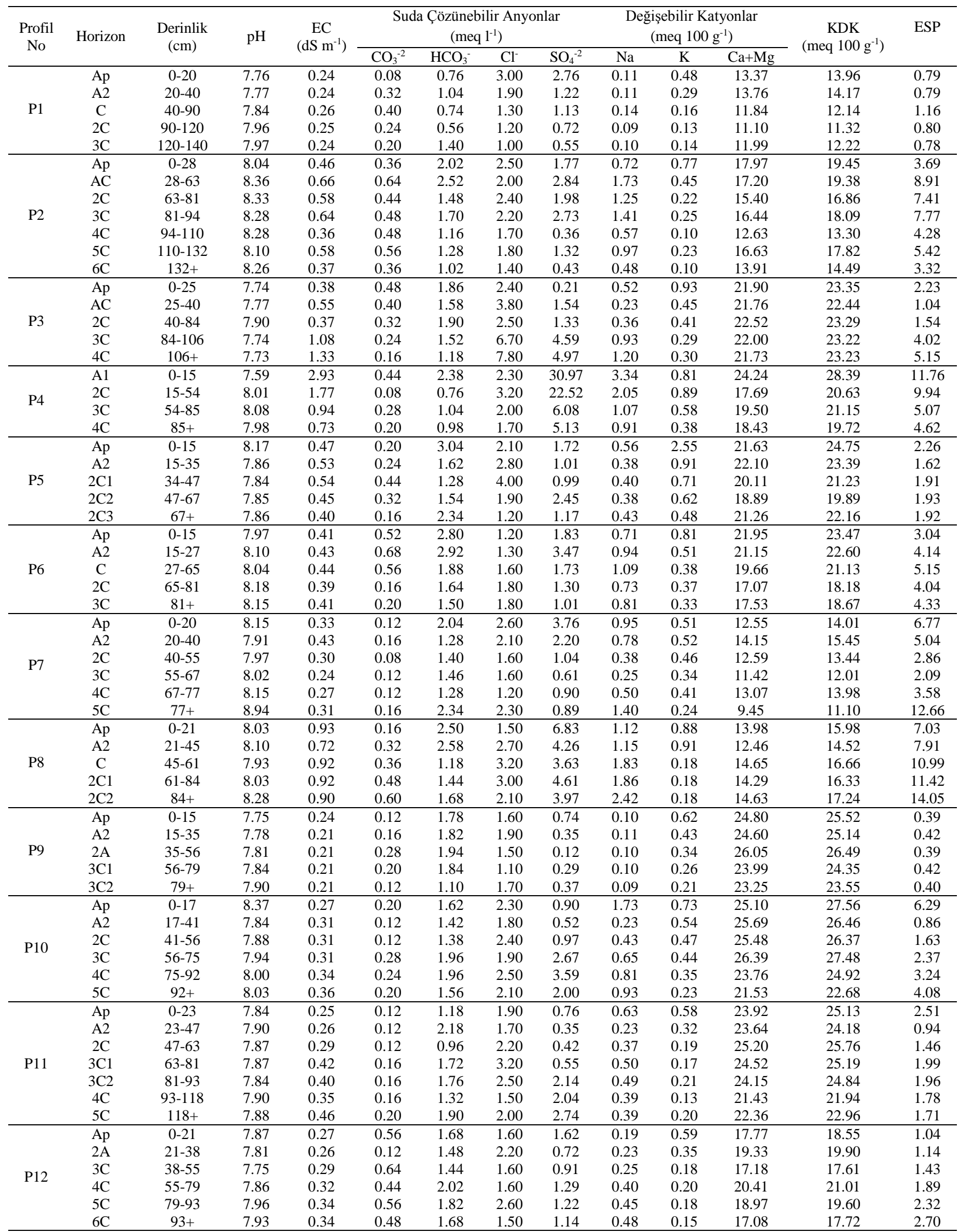


tespit edilmiştir. Araştırmacıların bu bulguları doğrultusunda, alüviyal fan üzerinde gelişen toprakların eriyebilir anyon konsantrasyonlarında göle yaklaştıkça artış göstermesinde toprakların genetiksel özellikleri ile birlikte göl suyunun yoğun anyon konsantrasyonundan sinırlıda olsa etkilendikleri belirlenmiştir (Çizelge 3).

Değişebilir katyonların GBS'deki dağılımı değerlendirildiğinde; profillerin horizonlarının tamamında $\mathrm{Ca}+\mathrm{Mg}$ katyonları $\mathrm{Na}$ ve $\mathrm{K}$ katyonlarına göre daha baskındır. En fazla $\mathrm{Ca}+\mathrm{Mg}$ miktarı 17.69-24.24 meq $100 \mathrm{~g}^{-1}$ arasinda değişen değer ile P4 profilinde tespit edilmiştir. GBS'de bulunan profillerin tamaminda $\mathrm{Ca}+\mathrm{Mg}$ miktarı üst horizonlardan alt horizonlara doğru azalmaktadır. DS'de bulunan P5 ve P6 profilleri arasinda en fazla $\mathrm{Ca}+\mathrm{Mg}$ miktarı 18.89-22.10 meq $100 \mathrm{~g}^{-1}$ ile P5 profilinde belirlenmiştir. P5 ve P6 profillerinde $\mathrm{Ca}+\mathrm{Mg}$ miktarı üst horizonlardan alt horizonlara doğru azalmaktadır. KDS'de buluna profiller arasında en fazla $\mathrm{Ca}+\mathrm{Mg}$ miktarı 21.53-26.39 meq $100 \mathrm{~g}^{-1}$ arasında değişen değer ile P10 profilinde belirlenmiştir. KDS'deki P7, P8 ve P12 profillerinde üst horizonlardan alt horizonlara doğru $\mathrm{Ca}+\mathrm{Mg}$ miktarı artma eğilimindeyken diğer P9, P10ve P11 profillerinde azalma eğiliminde olduğu belirlenmiştir. KDS'de bulunun profillerdeki ortalama $\mathrm{Ca}+\mathrm{Mg}$ miktarı diğer GBS ve DS' de bulunan profillere göre daha fazla olduğu tespit edilmiştir (Çizelge 3).

Katyon değişim kapasitesinin GBS'deki dağılımı değerlendirildiğinde; en fazla değer $19.72-28.39$ meq $100 \mathrm{~g}^{-1}$ değişim aralığı ile P4 profilinde tespit edilmiş̧tir. KDK değeri profillerin tamamında üst horizonlardan alt horizonlara doğru azalma eğilimindedir. Özellikle P4 profilinde alt horizonlara doğru kil miktarındaki önemli artışa rağmen KDK değerin azalmalar olduğu tespit edilmiştir. KDK'daki azalmanın ise smektit kil grubundaki ve organik madde içeriklerindeki azalma ile ilgili olduğu düşünülmektedir. DS'de bulunan P5 ve P6 profilleri arasında ise en fazla değer $18.89-22.10 \mathrm{meq} 100 \mathrm{~g}^{-1}$ değişim aralığ profillerin tamamında üst horizonlardan alt horizonlara doğru azalma eğilimindedir. KDS'de bulunan profiller arasında en fazla değer 21.94-39.34 meq $100 \mathrm{~g}^{-1}$ değişim aralığ profilinde tespit edilmiştir. KDK değeri artan kil miktarına bağlı olarak diğer profillerin aksine P8 ve P12 profillerinde alt horizonlara doğru artma eğilimindedir. KDS'de bulunun profillerdeki ortalama KDK miktarı diğer GBS ve DS'de bulunan profillere göre daha fazla olduğu tespit edilmiştir (Çizelge 3).

GBS'de bulunan profillerdeki Na miktarına bağlı olarak değişen ESP değerlendirildiğinde; en fazla değerler sırasıyla 0.42-11.76 ve 4.62-11.76 arasında değişim aralığ 1 ile P4 profilinde tespit edilmiştir. DS'de bulunan P5 ve P6 profilleri arasında ise en fazla ESP değeri sırasıyla 3.04-5.15 değişim aralıkları ile P6 profilinde tespit edilmiştir. KDS'de bulunan profiller arasında ise en fazla ESP değeri sırasıyla 7.03-14.05 arasındaki değişim aralıkları ile P8 profilinde tespit edilmiştir. P11 profilindeki değişim aralığını bu kadar fazla olması sadece yüzey horizonundaki $\mathrm{Na}+$ katyonun fazlalığından kaynaklanmakta olup diğer horizonlarda ESP değerleri oldukça düşük değerdedir. Alüviyal fan üzerinde gelişen topraklarımızın $\mathrm{Na}$ değerine bağlı olarak ESP değerlerinin göle yaklaştıkça artış göstermesinde toprakların genetiksel özellikleri ile birlikte göl suyunun yoğun $\mathrm{Na}$ içeriğinden de etkilendikleri belirlenmiştir (Çizelge 3).

\section{Sonuç}

Kuvaterner dönemde oluşan aluviyal araziler genellikle A-C horizon dizilimli genç topraklar olarak tanımlanırlar. Tarımsal potansiyelleri yüksek olmasına karşın çeşitli sorunlara sahip olan bu arazilerin, çok iyi tanımlanıp sınıflandırılması, haritalanması ve yetenekleri dahilinde kullanılması gerekmektedir. Araştırma alanımızdaki Kuvaterner yaşlı, alüviyal arazilerin üzerinde gelişen profiller incelendiğinde tamamının yüzey ve yüzey altı horizonlarında pedogenetik bir faaliyet olarak organik maddenin birikimi ve mineralizasyonu ile birlikte, belirli düzeyde toprak oluşumu ve profil gelişimi tespit edilmiştir. Jeogenetik proseslerin ve toprak oluşum süreçlerinin gereği olarak biriktirilmiş olan çeşitli kil minerallerin kolloidal etkileri sonucunda A horizonları oluşmuştur. Sürecin zamansal yetersizliği, fiziksel, kimyasal ve biyolojik ayrışma olaylarını sınırlandırmıştır. Toprak oluşum sürecinde özellikle kimyasal ayrışma ile nitelik kazanan, değişim dönüşüm ve yer değiştirmelerin yaşandığ 1 A horizonlarında çoğunluğu orta irilikte ve orta dayanıklılığa sahip yarı köşeli blok strüktürler gelişebilmiştir. Keza profillerdeki ayrışma-değişim-dönüşüm işlemlerinin bir sonucu olarak bazı profillerin (P1, P2, P4, P7, P9 ve P11) özellikle yüzey horizonlarında, renkte kısmen kırmızılaşmalar tespit edilmiştir. Renk ile açıklanan bu pedolojik gelişim, GB, DS ve KDS bulunan toprak profillerinde güncel göl sınırından uzaklaştıkça strüktür oluşumundaki artış ile desteklenmektedir. $\mathrm{Bu}$ tespitlerin tamamı değerlendirildiğinde, toprak profillerinin Kuvaterner dönemde oluşmaya başladığ ${ }_{1}$ düşüncemiz, literatür bulguları, arazi (profil) çalışmaları ve laboratuvar sonuçları ile desteklenmiştir. Nitekim profillerde tespit edilen A-C horizon dizilimi ve sınırlı pedogenetik ayrışma-değişim-dönüşüm işlemlerinin bulguları mekansal değişim düşüncemiz ile örtüşmüştür/kanıtlanmıştır. Özellikle, Burdur Gölü’nün güncel göl sınırlarına yaklaştıkça, pedogenetik ayrışma-değişimdönüşüm işlemlerinin azaldığı ve bitkisel üretimi sinırlandırabilecek kil içeriği, $\mathrm{pH}$ ve EC değerleri ile suda eriyebilir anyon ve katyon konsantrasyonlarında artışlar olduğu tespit edilmiştir. Sonuç olarak elde edilen bu verilerin alandaki arazilerin planlanmasında kullanılarak, günümüzde dramatik bir şekilde yok olan Burdur Gölü'nün ve çevresinin korunması ile ekolojik devamlılığının sağlanmasında katkı sağlayacağ düşünülmektedir. Burdur Gölü'nün ve çevresindeki arazilerin ekolojik dengelerinin devamlığı ile birlikte, ekosistem üzerinde olumlu dengeleri ve gelişmeleri beraberinde getirecektir. İyi yönde değişen ve gelişen çevresel koşullar ise yöre insanının doğaya ve doğal kaynaklara, farklı bir bakış açısıyla bakmasına yol açacak ve böylece toplumsal değişim ve gelişimin de boyutları genişleyerek ekosistem üzerindeki baskıları azaltacaktır.

\section{Teşekkür}

Bu çalışma, FBA-2017-2800 numaralı Araştırma Projesinin bir bölümüdür. Katkılarından dolayı Akdeniz Üniversitesi Bilimsel Araştırma Projeleri Yönetim Birimine teşekkür ederiz.

\section{Kaynaklar}

Altunbaş S, Sarı M (1998) Determination of relationship between the parent material and soil on red Mediterranean soil. International Symposium on Arid Soil, İzmir, Turkey. 
Altunbaş S (2005) Examination of degradation sizes of certain waterlands in lakes region at the level of substate. PhD Thesis. Akdeniz University, Graduate School of Science, Soil Science and Plant Nutrition.

Altunbaş S, M Sarı (2010) Türkiye ölçeğinde sulak alan yönetim planlarının durumu; Eğirdir gölü yönetim planı örneği. I. Ulusal Toprak ve Su Kaynakları Kongresi, Eskişehir, s. 34.

Altunbaş S, Sarı M (2011) Kurutulan Kestel gölünden kazanılan toprakların bazı özellikleri ile üretim potansiyelleri arasındaki ilişkiler. Akdeniz Üniversitesi Ziraat Fakültesi Dergisi 24(1): 6165.

Atalay İ (1977) Burdur havzası ve çevresinin jeomorfolojik gelişimi (Geomorphological evaluation of the Burdur Basin and its surroundings. Jeomorfoloji Dergisi 6: 93-110.

Atalay İ (2017) Türkiye Jeomorfolojisi. Meta Basım, İzmir.

Ataol M (2010) Burdur Gölü’nde seviye değişimleri. Coğrafi Bilimler Dergisi 8(1): 77-92.

Ayyıldız A (1990) Sulama suyu kalitesi ve tuzluluk problemleri. Ankara Üniversitesi, Ziraat Fakültesi Ders Kitabı 344, Ankara.

Beyhan M, Şahin Ş, Keskin ME, Harman Bİ (2007) Burdur gölü uzun periyotlu seviye değişiminin su kalitesi ve ağır metaller üzerindeki etkisi. Süleyman Demirel Üniversitesi Fen Bilimleri Enstitüsü Dergisi 11(2): 173-179.

Black CA (1965) Methods of Soil Analysis. Part 2, Amer. Society of Agronomy Inc., Publisher Madisson, Wilconsin, U.S.A., 13721376.

Bouyoucos GJ (1955) A recalibration of the hydrometer method for making mechanical analysis of the soils, Agronomy Journal 4(9): 434.

Bower CA (1959) Cation exchange equilibrium in soils. Affected by sodium salts. Soil Science 88: 32-35.

Dinç U, Şenol S (1990) Toprak etüt ve haritalama. Çukurova Üniversitesi Ziraat Fakültesi Ders Kitabı, No: 66, Adana, s. 108.

Dinç U, Şenol S, Sarı M (1991) Kahramanmaraş tarım işletmesi topraklarının etüt ve haritalanması. T.C. Tarım Orman ve Köyişleri Bakanlığı, Tarım İşletmeleri Genel Müdürlüğü, TİGEM Yayınları, Ankara.

Dinç, U, Şenol S (2013) Toprak etüd ve haritalama. Ç. Ü. Ziraat Fakültesi Genel Yayın No: 161, Ders Kitapları Yayın No: A-50 Çukurova Üniversitesi Ziraat Fakültesi Ofset Atölyesi, Adana, s. 235.

Evliya H (1964) Kültür bitkilerinin beslenmesi. Ankara. Üniv. Ziraat Fak. Yayınları, Yayın no: 36, Ankara, s. 292-294.

Fox RL, Olson RA, HF Rhoades (1964) Evaluating the sülfür status of soil by plants and soil test. Soil Science Society of Amerika. Procedings 28: 243-246.

Gözükara G, Altunbaş S, Sarı M (2017) Determination of land change near the Burdur Lake by using remote sensing and geographic information systems. 5th International Participation Soil and Water Resources Congress, Kırklareli, s. 24.

Gözükara G, Altunbaş S, Sarı M (2018) Evaluation of the effect of some climatic parameters on time-dependent spatial variation of lake burdur; 1975-2017. 2017. International Ecology 2018 Symposium. Kastamonu, s. 68.

Gözükara G, Altunbaş S, Sarı M (2019) Burdur Gölü'ndeki seviye değişimleri sonucunda ortaya çıkan lakustrin materyalin zamansal ve mekânsal değişimi. Anadolu Tarım Bilimleri Dergisi 34(3): 386396.

Gözükara, G (2019) Eski göl tabanlarındaki zamansal ve mekansal değişimlerin toprak oluşumuna etkileri. Akdeniz Üniversitesi, Fen Bilimleri Enstitüsü, Toprak Bilimi ve Bitki Besleme Anabilim Dalı, Doktora Tezi.

Hizalan E (1969) Toprak etüt ve haritalama I. Ankara Üniversitesi. Ziraat Fakültesi Yayınları 379, s. 218.

Jackson MC (1967) Soil chemical analysis. Prentice Hall of India Private'Limited, New Delhi.

Johnson CM, Ulrich A (1959) II. Analytical methods for use in plant analysis. California Agricultural Experiment Station Bull. 766.

Kacar B (1995) Bitki ve toprağın kimyasal analizler: III. Toprak Analizleri. Ankara Üniversitesi Ziraat Fakültesi Geliştirme Vakfi Yayınları No: 3.

Karaman ME (1990) Isparta güneyinin temel jeolojik özellikleri. Türkiye Jeoloji Bülteni 33: 57-67.

Mutlu HH (2010) Eski Konya gölü Kuvaterner terasları üzerinde oluşan toprakların jeokimyasal özellikleri ve ayrışma oranları. Selçuk Üniversitesi, Fen Bilimleri Enstitüsü, Toprak Bilimi ve Bitki Besleme Anabilim Dalı, Yüksek Lisans Tezi.

Roberts N, Karabiyıklığlu M, Jones M, Mather A, Jones G, Rodenberg I, Eastwood WJ, Kapan-Yeşilyurt S, Yiğitbaşığlu H, Watkinson M (2003) Climatic and tectonic controls over late quaternary sedimantation in the Burdur Lake Basin, Southwest Turkey, 3 rd International Limnogeology Congress, USA.

Sarı M, Altunbaş S, Sönmez NK, Emrahoğlu E (2003) Farklı fizyografik üniteler üzerinde yer alan eski Manay göl alanı topraklarının özellikleri ve potansiyel üretkenlikleri. Akdeniz Üniversitesi Ziraat Fakültesi Dergisi 16(1): 7-17.

Sarı M (2015) Taşınmış ana materyal ile yer şekilleri arasındaki ilişkiler. Toprak Etüd Haritalama El Kitabı. (Ed. Şenol S., Küsek G., Sarı M., Kurucu Y.) Ankara, s. 52-109.

Soil Survey Division Staff (1993) Soil Survey Manual. USDA Handbook 18, US Gov. Print. Washington DC.

Soil Survey Staff (1998) Keys to soil Taxonomy. 8th Edition, United States Departman of Agriculture, Natural Resources Conservation Service ISBN 0-16-048848-6. Washington DC.

Soil Survey Laboratory (2004) Soil Survey Laboratory Methods Manual. USDA Natural Resources Conservation Service. Soil Survey Investigations Report No 42. Washington D.C., USA.

Şenol S (2015) Toprak etüt haritalama işlem ve metodolojisi. Toprak Etüd Haritalama El Kitabı. (Ed. Şenol S, Küsek G, Sarı M, Kurucu Y). Ankara, s. 1-25.

Tudryn A, Tucholka P, Özgür N, Gibert E, Elitok O, Kamaci Z, Massault M, Poisson A, Platevoet B (2013) A 2300-year record of environmental change from SW Anatolia, Lake Burdur, Turkey. Journal of Paleolimnol 49: 647-662. 